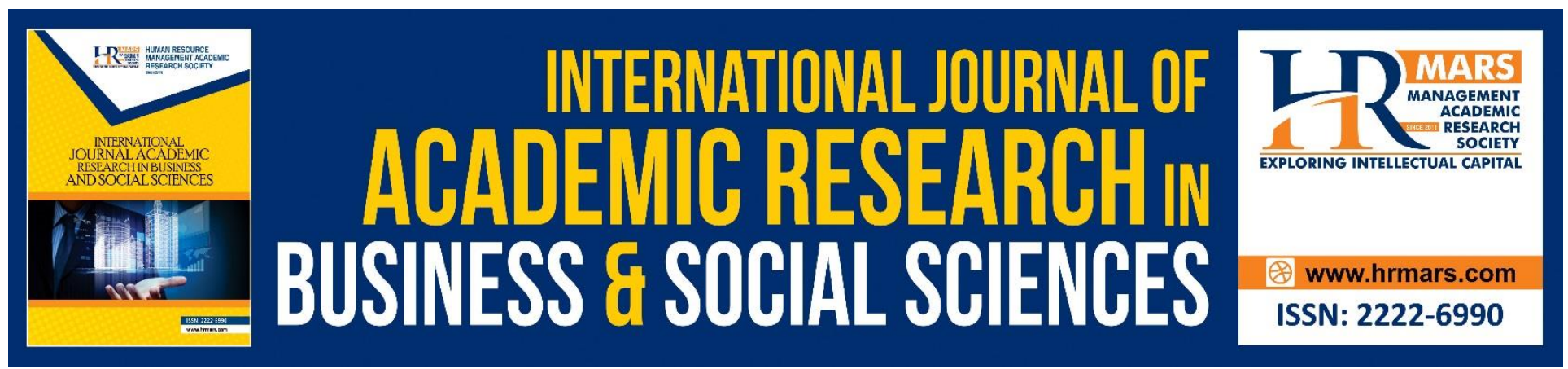

\title{
Tourism Service Design: Promoting Malaysia Cultural through National Brand in Kuala Lumpur International Airport (KLIA)
}

\section{Phoon Gar Chi, Muhammad Zaffwan Idris, Syed Osman Syed Yusoff}

To Link this Article: http://dx.doi.org/10.6007/IJARBSS/v8-i8/4624

DOI: $10.6007 /$ IJARBSS/v8-i8/4624

Received: 15 June 2018, Revised: 27 July 2018, Accepted: 30 July 2018

Published Online: 21 August 2018

In-Text Citation: (Chi, Idris, \& Yusoff, 2018)

To Cite this Article: Chi, P. G., Idris, M. Z., \& Yusoff, S. O. S. (2018). Tourism Service Design: Promoting Malaysia Cultural through National Brand in Kuala Lumpur International Airport (KLIA). International Journal of Academic Research in Business and Social Sciences, 8(8), 686-695.

Copyright: (C) 2018 The Author(s)

Published by Human Resource Management Academic Research Society (www.hrmars.com)

This article is published under the Creative Commons Attribution (CC BY 4.0) license. Anyone may reproduce, distribute, translate and create derivative works of this article (for both commercial and non-commercial purposes), subject to full attribution to the original publication and authors. The full terms of this license may be seen at: http://creativecommons.org/licences/by/4.0/legalcode

Vol. 8, No. 8, August 2018, Pg. 686 - 695

Full Terms \& Conditions of access and use can be found at http://hrmars.com/index.php/pages/detail/publication-ethics 


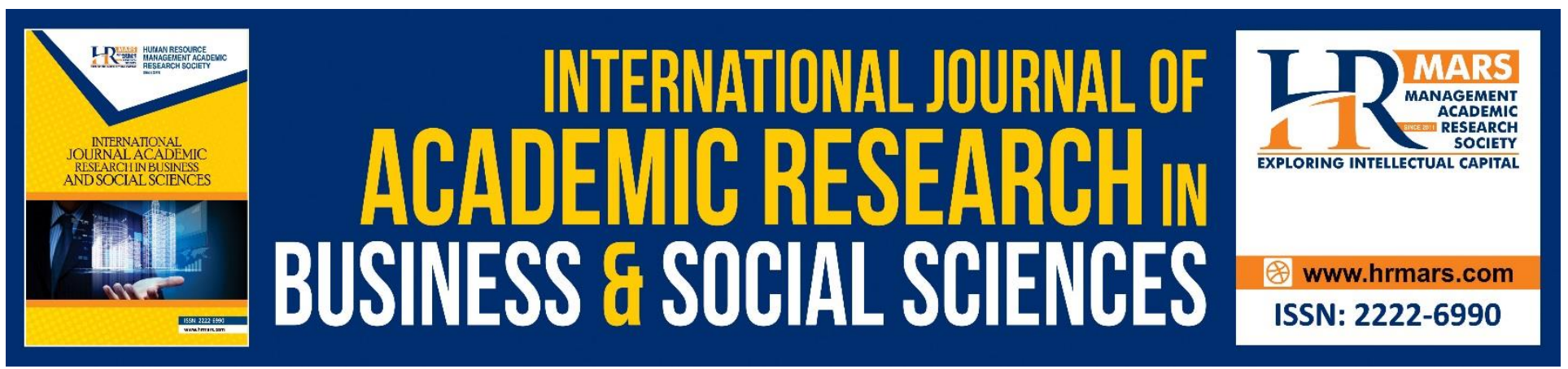

\title{
Tourism Service Design: Promoting Malaysia Cultural through National Brand in Kuala Lumpur International Airport (KLIA)
}

\author{
Phoon Gar Chi, Muhammad Zaffwan Idris, Syed Osman Syed Yusoff \\ Faculty of Arts, Computing and Creative Industry, Sultan Idris Education University, Perak, Malaysia
}

\begin{abstract}
Airport is a great place to exhibit local values and the spirits of a country. This research relates the international patron perception of Malaysia national brand provided in Kuala Lumpur International Airport (KLIA). The aim of the research is to explore how airport can becomes potentially an immersive space that evokes the local cultural to create a sense of place for travellers. Qualitative method is used for this research and a total of nine international participants responded to this study. Data collection methods included observation, workshop and interviews. The first phase consists of gaining customers' insight from various service design tools such as persona, user journey map and user experience prototype. Followed by second phase, semi-structured interviews with a brand expert. The data were analysed using a qualitative data analysis program, NVivo12, to developed 'coding' process. The findings of national brand elements exist in KLIA consists of Nation's Icon; Flora, Fauna and plants; Tourism and Topography; Food; Landmark; Costume and Handicraft. Results could be used as a starting point for introducing the Malaysian culture through adding of the video playing of Malaysia attractions; Games and Art; Malaysian music; providing a taste of Malaysian food; promoting on Malaysian Borneo cultural features; providing local culture ambience; digitalization; seasonal events; constructing identity through festivals and utilized various Malaysian musical instrument in the KLIA. This will help the airport to promote Malaysia within the context of airport service environment. KLIA will become another tourists' attraction in terms of customer experience. Keywords: National Brand, Service Design, National Identity, Malaysia Cultural, Tourism.
\end{abstract}

\section{Introduction}

The airport isn't a destination for air travellers. This is the transition point that connects people to business and loved ones. Today our customers expect a modern spirited airport to provide a consistent, effective and immersive experience the minute they reached airport. The best airports are now constantly exceeding these basic requirements and are evolving to continuously improve the experience. Creating a sense of place within and through the airport is a popular concept, since airports are the natural gateways and often the first point of contact with the local destination and 
INTERNATIONAL JOURNAL OF ACADEMIC RESEARCH IN BUSINESS AND SOCIAL SCIENCES Vol. 8, No. 8, August 2018, E-ISSN: 2222-6990 @ 2018 HRMARS

local cultural (Losekoot, 2015). Many airports are like a shopping mall, restaurant row and cultural experience - all under one roof. Besides the physical elements, visitors can also experience a slice of the region's culture without leaving the building and extend their travel experience by consuming more of what they enjoyed throughout their trip. This is the opportunity to educating foreigners of Malaysian culture during their arrival at the airport. As Malaysia is one of the well-known nation with linguistic, religious and cultural attractions. Thus, the transformations should carry out for passenger to seek new ways to not only entertain themselves but to spend their waiting time for the flight meaningfully. However, the first and the last impression of international passengers towards that particular country are encountered during the time they visit to the airport (Chao, Lin \& Chen, 2013).

\section{National Identity}

National Identity is the identity of a person or a sense of belonging to a country. This is a cohesive whole in the national sense, represented by a unique traditions, language, politics and culture (Tavarez DaCosta, 2018). For instance, by considering the relationship between culture and nationalism to distinguish the uniqueness of national identity among countries (Inac \& Unal, 2013). A few scholars have studied the significance of local culture and national identity as the main attraction for tourist to visit a foreign country (Urosevic, 2012). According to Ali and Amin (2014), there are a few major factors for instance learning about the local cultures and traditions, which able to induce them to travel abroad.

\section{Nation Brand}

Nation brand is an important concept in today's world (Dinnie, 2015). A nation brand strength into a better perspective, as well as the country's export volume increases, foreign investment and attracting tourism (Matiza \& Oni, 2014). Generally, nation brand as part of a national strategy for building positive image and reputation in most of the studies (Handayani \& Rashid, 2013). In addition, the nation brand expands its scope not only to build a positive image, reputation and gain more international market share, but also to consolidate its position on the international stage (Prucpairojkul \& Triamsiriworakul, 2008). A nation brand is the total sum of all perceptions of a nations to its people, culture and heritage, investment and immigration, export brand, tourism and governance (Che-Ha et al., 2016).

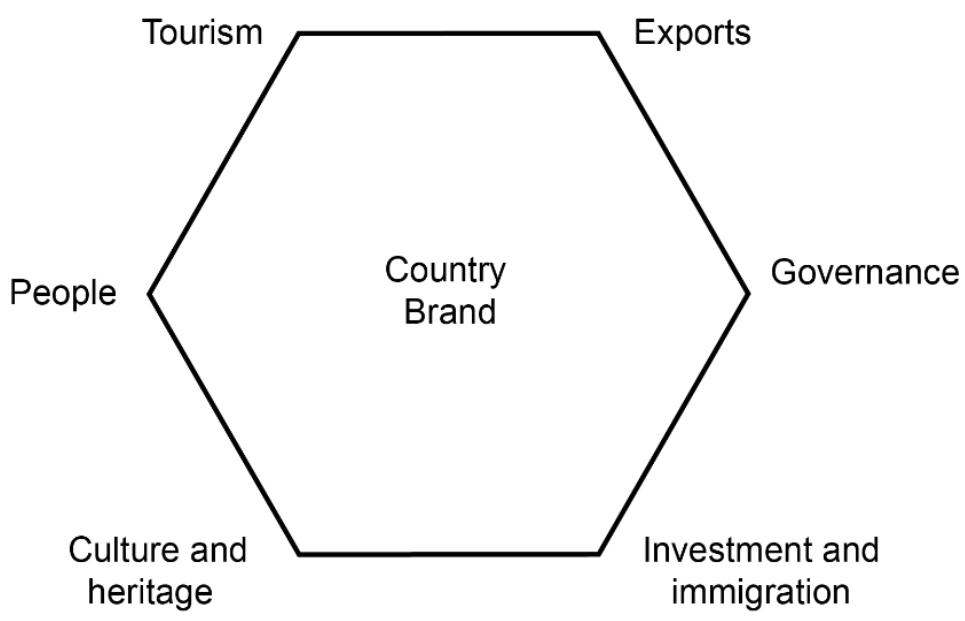

Figure 1. Nation Brand Hexagon (Anholt, 2002). 


\section{Service Design}

Service design helps to innovate the services by bringing new ideas to service industry to improve the quality of your service using design thinking, tool and method (Gianelli, 2016). The tools mention here is to help researchers to analyse their thoughts and familiarize them to philosophy service design. The persona is a hypothetical prototype of real users' (Ferreira et al., 2015). Personas are fictitious characters that represent the needs and requirements of larger user community in terms of personal characteristics and goals (Eriksson, Artman \& Swartling, 2013). In order to describe personas, it is important to specify their characteristics in image, name, age, occupation, friends and family (Queiros et al., 2015). Customer journey map is a service design tool to demonstrate a service experience from the customer's perspective (Sarmakari, 2018). Customer journey mappings may involve steps, touchpoint identification, potential issues and experience reports (Crosier \& Handford, 2012). Customer journeys are described in detail as a series of touchpoints or interactions between the customer and the service providers (Voorhees et al., 2017). In the case of services management and service marketing frameworks, innovation methods will usually implement in service design ( $\mathrm{Yu}$, 2017). The process is a series of workshop, offerings, needs and experience (Bækkelie, 2016).

\section{Methodology}

This study involves the process of identifying key factors in the Malaysia identity, in order to know whether the existing promoting strategies provide by airport gives a unique opportunity for foreigners to delve into richness of Malaysian culture.

To establish a unique Malaysian experience at KLIA, the standard is chosen in two stages: international student interviews and brand expert interviews. First, international student interviews include in-depth interviews using the service design tools such as persona and customer journey map to gain deeper understanding of users. Selecting international students from countries and regions of Asia, Europe and America as the target of the respondent. In this case, foreigners to Malaysia are considered to be experience Malaysian national brands around KLIA will be studied. Second, semistructured interview with brand expert in areas of branding to identify and assess the dimensions and standards of Malaysia national brands. Types of brand expert interviews is personal. 
INTERNATIONAL JOURNAL OF ACADEMIC RESEARCH IN BUSINESS AND SOCIAL SCIENCES Vol. 8, No. 8, August 2018, E-ISSN: 2222-6990 @ 2018 HRMARS

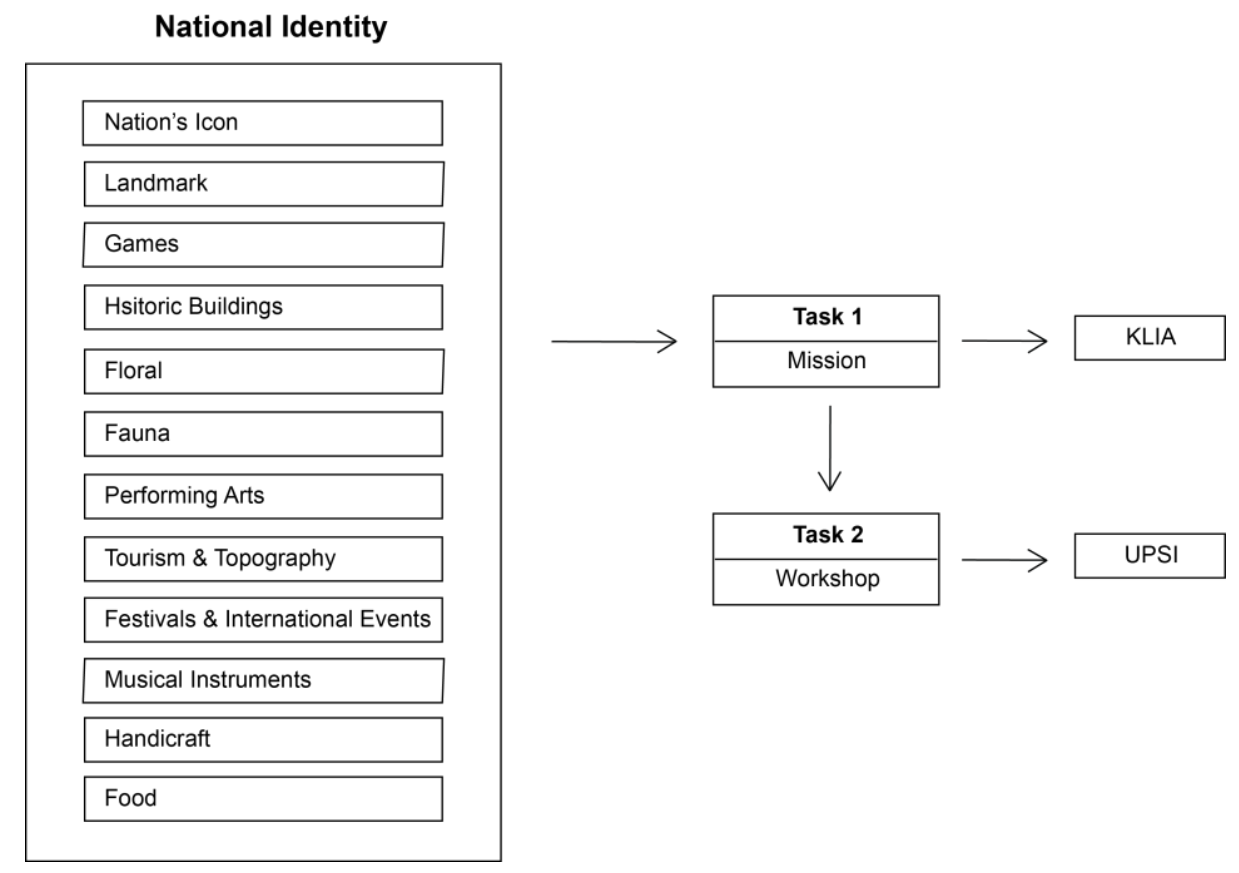

Figure 2. Data Collection Framework

Data collection procedures are divided into two tasks. The first phase is to collect data on national identity in KLIA. Researcher conducted studies groups of international students at KLIA public area. Each of international students has a mission to complete. A piece of KLIA arrival and departure area map are issued to each of them to get their insight and experience in a specific location. Besides that, international students identified the areas of existing promotional available in KLIA. On-site evaluation had made by. Each of the international students walk around the place and explore themselves. This is to check out which areas of KLIA highly or lowly promotes the Malaysian identity and stick the representative colour stickers on the map. Cameras were used to snap photos on satisfied or dissatisfied things that relates on promoting Malaysia in KLIA.

The second phase is to gather the international students together and form a workshop session after their experience in KLIA. Students are bringing together to make a clear vision and to clarify a common understanding. The design workshop is used to convey the idea of a comprehensive view of customer experience. This is to get information from the international students' perspective. The workshop session will be divided to three: interviews, customer journey maps and user experience prototypes. This phase is to discover international student's needs through journey mapping and ethnographic research. Based on tangible new insights, researcher will alleviate possible customer experience pain points, frustrations and recommendations.

\section{Results and Findings}

This findings is focusing on identifying the national identity that exist in airport from international students. A number of touchpoints were mentioned through students' experiences in KLIA. Table 1 lists several promotional activities around airport, the actual experiences of students of each of the students' journey. 
INTERNATIONAL JOURNAL OF ACADEMIC RESEARCH IN BUSINESS AND SOCIAL SCIENCES

Vol. 8, No. 8, August 2018, E-ISSN: 2222-6990 @ 2018 HRMARS

Table 1. National Identity in KLIA

\begin{tabular}{ll}
\hline National Identity & Arrival Area \\
\hline Nation's Icon & Departure Area \\
\hline Landmark & \\
\hline Games & \\
\hline Historic Buildings \\
\hline Flora, Fauna \& Plants \\
\hline Costume \\
\hline Performing Arts \\
\hline Festival \& International Events $\&$ Topography \\
\hline Musical Instruments \\
\hline Handicraft \\
\hline Food
\end{tabular}

There are the twelve elements to a national brand used in an airport. By the description of the students, they are currently experiencing nation's icon, landmark, plants, costume, tourism, handicraft and food at different areas of the airport. This is especially more promotional on departure area. Besides, these are the things they only can differentiate with Western culture. Consequently, the promotion of Malaysia to foreigner at arrival area is less compared to departure area. On the contrary, no students mentioned arrival area make on any inspiration. Actually, arrival area is extremely important where foreigners are first contact with Malaysia when they reached Malaysia. To some extend, there remain many empty spaces at arrival public area. Every international student involved with the airport experience has a common focus - the delivery of a positive, educative and a memorable Malaysian culture.

\section{User Experience Paper Prototype}

The next stage of the role-play used to act out scenarios for user journeys and to explore the information flow and characteristic of the persona's search behaviour. The prototyping experience were going one by one, and relevant points were added to existing touchpoints or new touchpoints were made. 


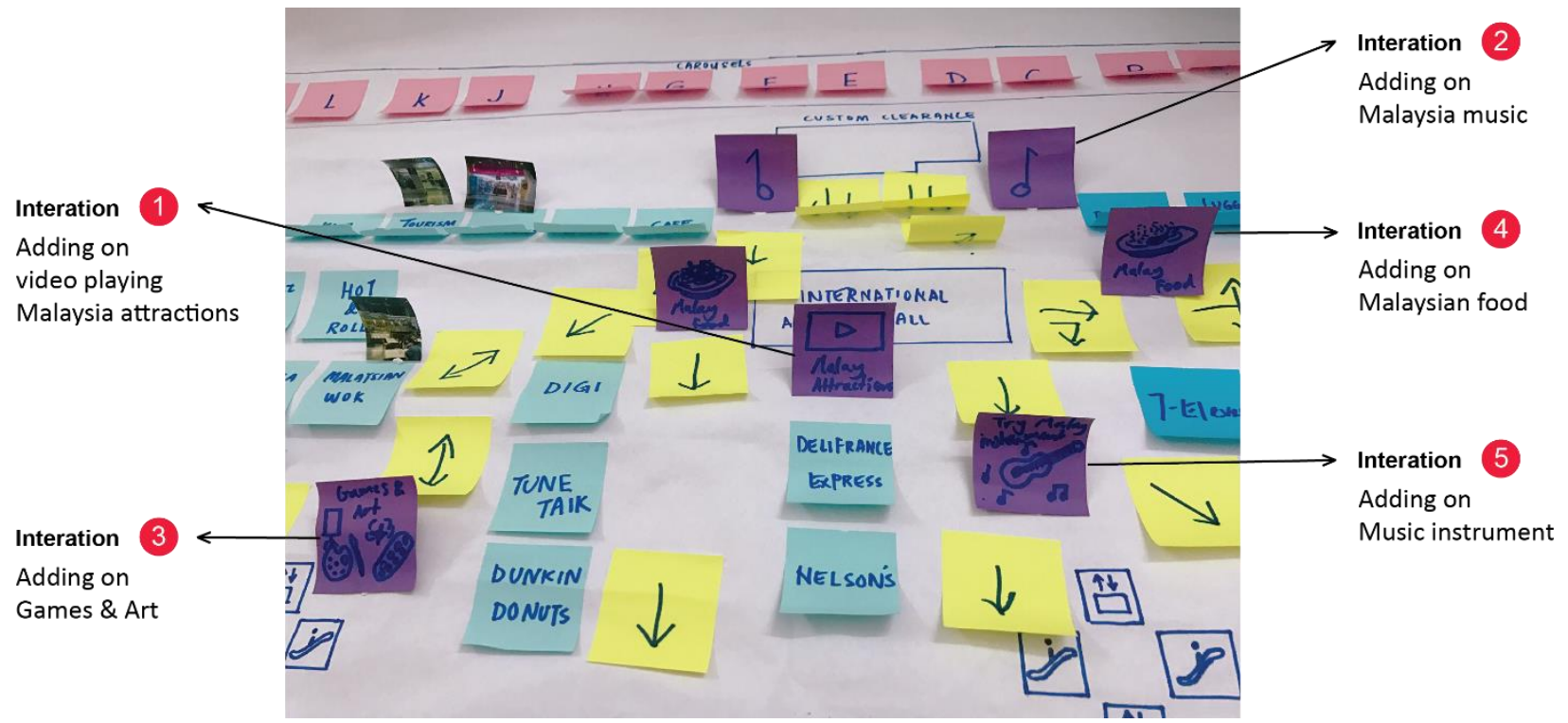

Figure 3. Interation on Arrival Area

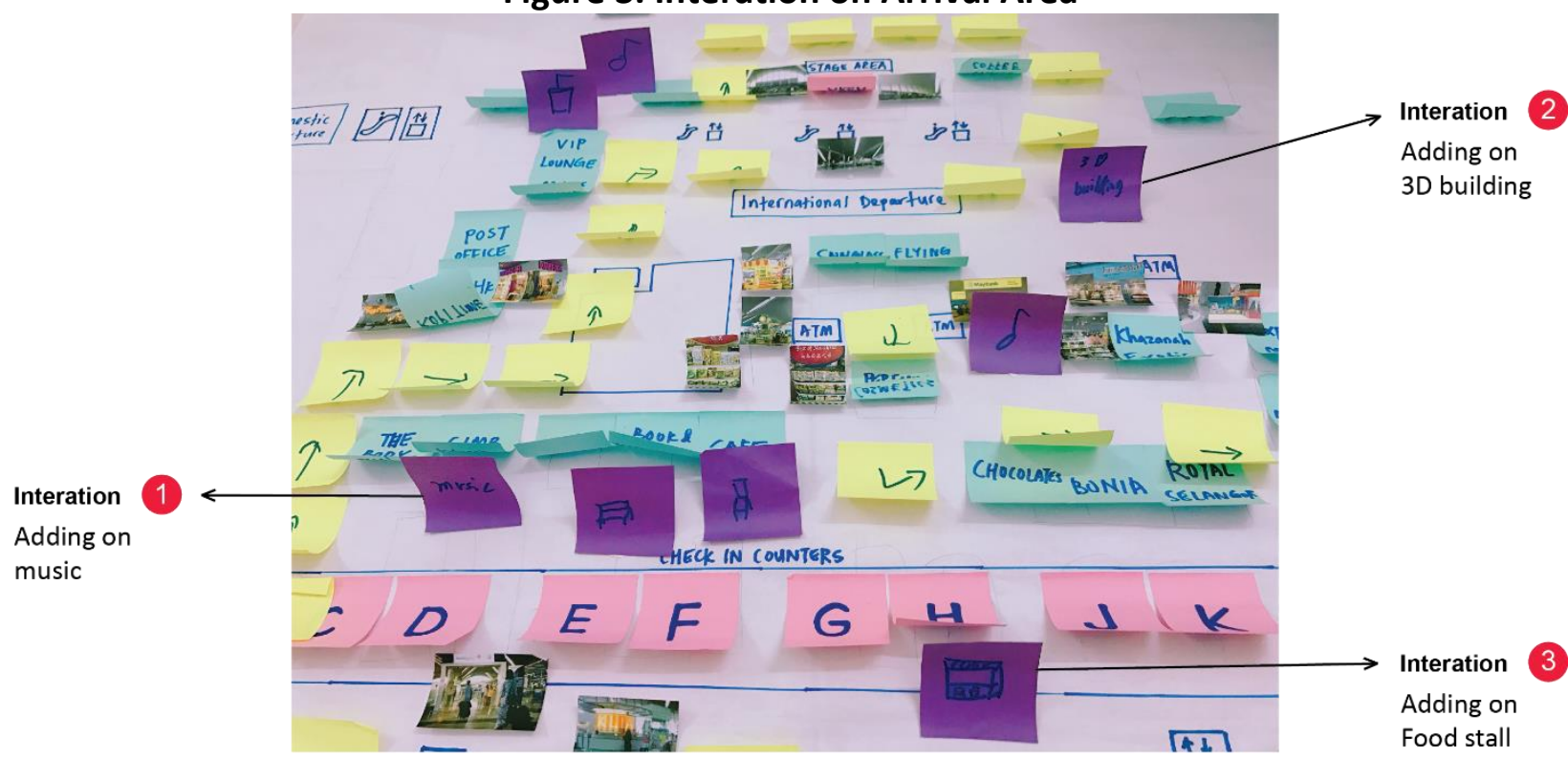

Figure 4. Interation on Departure Area

A number of international students suggested developing an area with showcased with Malaysia local culture that will exhibit the overview of the distinctive Malaysian arts and culture. Apart from the food and retail shop, quite number of international students had commented, "I was thinking of after having food and buying things, there is no other things to keep me entertained in airport" (PRP S5, 08/04/2018). Another international student commented on their long stay in the airport for about five to six hours or even eight to ten hours wait in the airport and trying to look for things to do and said,

5-6 hours or sometimes 8-10 hours in the airport - there's worse. I'm thinking of where can I go or get moved on? (PRP S4, 01/04/2018).

Another international student gives a very good sense of what it is like to be 'stuck' in an airport, When I waited at the airport for about seven hours and would like to be able to go to a movie theatre for some of it. Or maybe a museum or gallery to look at? Or maybe 
INTERNATIONAL JOURNAL OF ACADEMIC RESEARCH IN BUSINESS AND SOCIAL SCIENCES

Vol. 8, No. 8, August 2018, E-ISSN: 2222-6990 C 2018 HRMARS

some screen with local movies? Just something to look at while you are filling in

those long hours - or even some performance would be good. (PRP S9, 08/04/2018).

Students determined by providing the Malaysian cultural experience in the airport so that every passenger will know what it means by Malaysian. By developing a Malaysian cultural area that will exhibit the overview of the distinctive Malaysian arts and culture. Organised musical concerts, museums that are located inside an airport terminal building, experience Malaysian culture traditional costumes, local festivals, dance performances and musical instrumental performance.

Students explained the sense of place at KLIA should include promotion of local events and festivals, exposes travellers to the sights, sound and flavours of Malaysian culture, and references of Malaysia's history. Provide an area with an overview of festivities to look forward to while visiting Malaysia. There are many festivals and celebrations in Malaysia.

I am interested in traditional festivals in Malaysia. Hard to find at the airport. (PRP S9, 08/04/2018).

\section{Discussion}

This research has explored the current national brand and promotional strategy in KLIA, based on the international students' exploration and experience as well as brand expert recommendations. However, national identity such as games, historic buildings, performing arts, festivals and international events, and musical instruments have not been promoted in KLIA.

From the students' point of view, most of them only experienced Western culture and cuisine at KLIA, while Malaysian culture and food are few and far between. Several of Malaysia's national identity around KLIA were figured out, but there had been quite limited. National brand elements exist in KLIA consists of nation's icon; flora, fauna and plants; tourism and topography; food; landmark; costume and handicraft.

From the view of brand expert, shape of Malaysia's national identity has been a crucial part. Promoting national unity in multicultural Malaysia is based on the percentage of the population. The promotional efforts extend to other potential local cultural such as Wayang Kulit, Wau Bulan and batik activities to highlight Malaysia experience to tourists. Additionally, side events like handicraft has to be continuous exposure and offering non-seasonal treats. Nowadays, the phenomenon of digitization is reaching an inflection point, it is necessity of digitalizing cultural objects to be invented in airport. Various traditional costumes, dances, arts, handicrafts and music of Borneo is inadequate.

Many airports are unable to deliver superior customer experience nowadays. Customer base should be segmented in meaningful way to make smart investments in future; service models and solutions should be made. Building a customer experience is not easy. In terms of demographics, behaviours, attitudes and a deeper understanding, it requires discipline, investment and a deeper understanding of customers. The cooperation between the airport and the tourism could create a stronger, more complete value proposition for customers, spanning the entire journey, besides educating them with local culture. This believe will create a significant opportunity to be enriched culturally, while inspiring and educating millions of passengers every year. This will become part of the overall solution in reducing the negative impact. 
INTERNATIONAL JOURNAL OF ACADEMIC RESEARCH IN BUSINESS AND SOCIAL SCIENCES Vol. 8, No. 8, August 2018, E-ISSN: 2222-6990 @ 2018 HRMARS

\section{Conclusion and Future Research}

This research was developed in order to explore the current national brand and promotional strategy in KLIA based on the students' exploration and experience. Due to students prototyping, introducing Malaysia culture through adding on video playing of Malaysia attractions; Games and Art; Malaysia music; provide a taste of Malaysian food and utilized various Malaysian musical instrument in the KLIA. While brand expert suggestions for integrated smartphone apps; digitalization for airports; providing local culture ambience or areas; digital advertising; seasonal events and constructing identity through festivals. Furthermore, the future research could implement almost the same methods used in this study for different nationalities transfer foreigners. The second direction, future research could replicate the study by interviewing different interest group such as tourism industry representative and airport management representative. Airport Malaysia can be associated with Tourism Malaysia in planning and implementing tourism promotion activities in KLIA. Additionally, promote more on Malaysian Borneo cultural features. This research aims to create guidelines for the creative industry especially service design industry. Besides that, the guidelines are also produced a reference to the Airport Management, Malaysia Airport Berhad and other researcher about the promotional strategy of Malaysia identity in airport. Small and medium enterprises (SMEs) to be showcased at Malaysian Airports to project their brand globally. In marketing field, tend to extensively utilize mass-media advertising in order to build audience awareness, and they are the most recognizable type of local brand to mass audiences. The results could be used as a starting point for creating solutions and innovative ways for improving customers experience towards Malaysia cultural. With the proper promotional strategy, Malaysia history and culture starts being interesting for the others.

\section{Corresponding Author}

Phoon Gar Chi

Faculty of Arts, Computing and Creative Industry, Sultan Idris Education University, Perak, Malaysia

Email: phoongarchi@gmail.com

\section{References}

Ali, F., \& Amin, M. (2014). The influence of physical environment on emotions, customer satisfaction and behavioural intentions in Chinese resort hotel industry. Journal for Global Business Advancement, 7(3), 249-266.

Anholt, S. (2002). Nation branding: A continuing theme. Journal of Brand Management, 10(1), 5960.

Bækkelie, M. K. (2016). Service design implementation and innovation in the public sector. Proceedings of NordDesign 2016, NTNU, Trondheim, Norway (10-12 August).

Chao, C. C., Lin, H. C., \& Chen, C. Y. (2013). Enhancing airport service quality: A case study of Kaohsiung international airport. Journal of the Eastern Asia Society for Transportation Studies, 10, 2235-2254.

Che-Ha, N., Nguyen, B., Yahya, W. K., Melewar, T. C., \& Chen, Y. P. (2016). Country branding emerging from citizens' emotions and the perceptions of competitive advantage: The case of Malaysia. Journal of Vacation Marketing, 22(1), 13-28.

Crosier, A., \& Handford, A. (2012). Customer journey mapping as an advocacy tool for disabled people: a case study. Social Marketing Quarterly, 18(1), 67-76. 
INTERNATIONAL JOURNAL OF ACADEMIC RESEARCH IN BUSINESS AND SOCIAL SCIENCES Vol. 8, No. 8, August 2018, E-ISSN: 2222-6990 @ 2018 HRMARS

Dinnie, K. (2015). Nation branding: Concepts, issues, practice. Routledge.

Eriksson, E., Artman, H., \& Swartling, A. (2013, April). The secret life of a persona: when the personal becomes private. In Proceedings of the SIGCHI Conference on Human Factors in Computing Systems (pp. 2677-2686). ACM.

Ferreira, B., Silva, W., Oliveira Jr, E. A., \& Conte, T. (2015). Designing Personas with Empathy Map. In SEKE (pp. 501-505).

Gianelli, E. (2016). The adoption of service design methods and tools by Nordic technology startups. Handayani, B., \& Rashid, B. (2013). Conceptualisation of nation brand image. International Journal of Management Studies (IJMS), 20(2), 165-183.

Inac, H., \& Unal, F. (2013). The construction of national identity in modern times: Theoretical perspective. International Journal of Humanities and Social Science, 3(11), 223-232.

Losekoot, E. (2015). Factors influencing the airport customer experience: A case study of Auckland International Airport's customers (Doctoral dissertation, Auckland University of Technology). Matiza, T., \& Oni, O. A. (2014). Re-imaging African nations as preferred foreign direct investment destinations: Towards a sustainable nation brand-based framework. Mediterranean Journal of Social Sciences, 5(9), 663.

Prucpairojkul, P., \& Triamsiriworakul, S. (2008). Thailand's Nation Branding: A study of Thai nationbrand equity and capabilities. Akademin för hållbar samhälls-och teknikutveckling.

Queiros, A., Cerqueira, M., Martins, A. I., Silva, A. G., Alvarelhão, J., \& Rocha, N. P. (2015). Personas and Scenarios Based on Functioning and Health Conditions. In Human Factors in Software Development and Design (pp. 274-294). IGI Global.

Sarmakari, J. (2018). Service design as a tool for improving customer experience.

Tavarez DaCosta, P. (2018). Globalization, Foreign Languages and National Identity. Online Submission.

Urosevic, N. (2012). Cultural identity and cultural tourism: Between the local and the global (a case study of Pula, Croatia). Singidunum Journal of Applied Sciences, 9(1), 67-76.

Voorhees, C. M., Fombelle, P. W., Gregoire, Y., Bone, S., Gustafsson, A., Sousa, R., \& Walkowiak, T. (2017). Service encounters, experiences and the customer journey: Defining the field and a call to expand our lens. Journal of Business Research, 79, 269-280.

Yu, E. (2017). A Reflection on and Suggestion of Service Design Processes. Archives of Design Research, 30(1), 25-38. 